\title{
FINANCING SMALL HOUSES ${ }^{1}$
}

\author{
BY JOHN IHLDER ${ }^{2}$ \\ New York
}

$\mathbf{M}^{\circ}$

OST human minds are so constituted that they cannot confine their attention to negatives for any considerable length of time. The law since-and probably before-the time of Moses has dealt chiefly in negatives. Thou shalt not do certain things specified; but all else is permitted until a new law imposes a further restriction. Such prohibitions are essential to any orderly progress. They are the rules of the game without which there could be no game, and since the beginning of time the rule maker who made wise rules has been honored. But for the rest of us, learning the rules is merely the starting point. After that comes the really interesting task of working, according to the rules, better than anyone else. This we call "constructive." And it is interest in constructive work that has begun to grip many who see the need of bettering our housing conditions. Laws we must have which will forbid our sacrificing the fundamentals of wholesome housing, such as light, air, sanitation, water supply, privacy, protection against fire. Then the field lies open; with these rules accepted who can show us how to provide dwellings that are both better and cheaper than the ones we now build?

Of course this game is old. It began before any records were kept. In modern times the commercial builder has made great progress in it. Recently a combination of business and philanthropy has added a new feature or two. For all that there seems still to be more unlearned than has yet been learned. A new zest has been given by the housing movement that has spread across the country with such remarkable rapidity during the past four years. The commercial builder and the architect have made the dwellings of well-to-do citizens marvels of convenienceat least they would be so considered by past generations-but they have not done so much for the every-day citizen. To be sure they have given him lights and tubs and toilets, which he already considers necessities and which the rules of the game now often require. But they have either packed him into a flat or given him a house which presupposes the existence of non-existent servants.

Is this the best that can be done for him? Must his family sink its individuality in a modern cliff dwelling or else support the butler's pantries of the plutocrat? Several conferences during the past winter have de-

'See article on "Housing at the Los Angeles Conference," Vol. II, page 68.

2 Field Secretary, National Housing Association. Editorial writer, Grand Rapids Evening Press, 1902-1908. Secretary, Municipal Affairs Committee, Grand Rapids, 1908-1910. Cornell University, B.S. 1900.-EDIroR. 
clared that it is not; but if it is not there are some questions to be answered. The number of these questions is indicated by the special committees appointed on the recommendation of the section meeting on factors in the cost of small houses at the last conference of the National Housing Association.

These committees are to study:

Methods of financing small houses.

Materials and cost of construction.

Street improvements.

Land subdivision.

House plans.

Accounting methods.

Methods and costs and social welfare.

Effect of building and housing codes on cost of construction and maintenance.

So far the first question has taken most of our attention-which perhaps is not surprising in view of the practical nature of the subject. There are in various parts of the United States and Canada a number of individuals and organizations which have undertaken to build improved wage-earners' houses. Each is keenly interested in all the phases of the others' work; type of house, floor plans, thickness of walls, building materials; but first, last and all the time, each wishes to know how the others get their money. Some, with very short experience, believe that if this question is answered, the rest will be easy. Some, with rather longer experience, know that after financing comes building, and that building, especially when every cent counts, presents problems that have not yet been wholly solved. Their dream is that management will prove easy. Those with the longest experience have learned that no part of the game is easy. But they have also learned that the game is so interesting that once in it they won't drop out.

It was financing that held the center of the stage during the past winter. There are two rules in this financing; First, dividends must be limited to a fair return on the investment. So far this has been held to be five per cent or six per cent net. It is no part of the game to gamble on speculative rises in value, for the houses are to be provided at as low a price or rental as is commercially feasible. Nor is it any part of the game to provide houses on the basis of charity. They must pay a fair return on the investment. Second, a reserve or sinking fund must be created that will enable the owners to scrap the houses when they have outlived their usefulness, say in forty or fifty years. These builders do not propose to inflict upon their cities in the future the burden those cities now bear in the form of antiquated dwellings whose owners apparently labor under the delusion that a building is never worn out unless it falls down

The first conference of the year at which the question of financing was 
discussed was that of the National Municipal League at Toronto, last November. There G. Frank Beer, president of the Toronto Housing Company, presented a paper describing the Ontario method. ${ }^{8} \mathrm{He}$ started with the following assumptions: A large amount of money is needed; for Toronto, like most other thriving industrial cities, is woefully underhoused so far as the wage-earner and especially the unskilled wageearner is concerned. This money must be obtained at a cheap rate of interest in order that rents may be kept down. Large amounts of money at cheap rates of interest are not to be obtained through private agencies, at least not in a new country where investors find tempting chances for investment at two or three times 6 per cent. "Ontario as a whole and Toronto in particular is faced with a development which demands our entire financial resources to supply the necessary industrial expansion and trade credits." Then he added: "Housing is a communal responsibility. If individual initiative fails to supply decent houses in which our citizens may live, it is the duty of the city or state to supply the need, or to bring about some means by which the need will be supplied."

So the group of men represented by Mr. Beer secured from the provincial legislature an act authorizing a city to guarantee the securities of housing companies up to eighty-five per cent of their value. The plan embodied in the act is as follows:

1. Permission to form under the joint stock companies act a company having a share capital and the necessary powers to carry out the objects in view. Shares in such company to be sold at par and to an amount sufficient to provide the necessary margin for the securities to be issued by the company. If the shareholders provide fifteen per cent of the cost required to purchase lands and erect dwellings, etc., the municipality may assist by its guarantee of securities in raising the balance.

2. If the council of the municipality is satisfied that additional housing accommodation is urgently required and that the main object of the company is to give bona fide help in supplying such need and is not to make profit, the council may pass a by-law authorizing and providing for the giving of the guarantee. The act also provides that the council or a committee of the council, before the guarantee is given, must approve of the location of the lands and of the general plans for the houses.

3. Provisions are made with reference to the deeds of trust, the kind of securities, form, etc., and for the issue of further securities from time to time as additional lands are acquired and improvements made, provided however, that the total amount of guaranteed securities outstanding shall not exceed eighty-five per cent of the value of the lands, dwellings, etc.

4. The council of the municipality guaranteeing the securities shall appoint a member of the board of directors of the company. The books of the company shall at all times be open to inspection on behalf of the municipality.

'See Natronal Municipal Review, Vol. III, page 237. 
5. No dividend on the capital stock of the company shall be paid exceeding six per cent per annum.

6 . If the municipality desires to acquire the holding of the company it may do so by purchase of the shares in the open market or by the company passing a by-law transferring its holdings. In such case no greater premium than ten per cent shall be paid for the shares of the company.

7. The principle embodied in the act is that the municipality may ultimately become the owner of the properties but as municipal management is not likely to prove as efficient as management by private individuals deeply interested in this work, the creation of a board of trustees is provided for to receive and hold the shares purchased, given or bequeathed. This board shall be established upon terms agreed upon by the company and the municipality.

8. To prevent any watering of stock or the making indirectly of any profits by land-owners, contractors, etc., the act provides that no stock in the capital of the company shall be sold for any consideration other than cash, and that money received by the company on account of its capital stock shall not be used for expenditures not connected with the carrying out of the main purpose of the company.

9. An important provision is likewise included whereby the guarantee of securities by the municipality is made possible without a vote of the ratepayers if the by-law providing for such guarantee is approved of by the provincial board of health.

The three underlying principles, said Mr. Beer, are: private initiative government encouragement and guidance, public coöperation.

In the discussion which followed it was argued that this plan embodies certain dangers. First, there is the upsetting of our theory of the function of government. The function of government has been, to most of us, the holding of the scales, seeing to it that the members of the community deal with each other fairly and in such a way as to best serve the interests of all. It is not the function of government, according to this theory, to become a competitor while at the same time retaining the judicial office. However that may be, the practical question is, what will be the effect of having the government build houses, or loan its credit for the building of houses? Leave out the item of unfair competition with other builders who must pay commercial rates for their moneyit is argued that commercial builders either are not erecting houses for the class of people under consideration, or, if so doing, are erecting houses below a wholesome standard which consequently are against the public welfare. Consider only the effect of the government both setting minimum standards and at the same time building houses. The government at once faces this dilemma, an unusual dilemma, for it has at least three horns: the houses must conform to the standards set, they must pay a fair return on the investment, they must rent within the means of the unskilled workman. 
It is assumed that the standards are the minimums which will permit of wholesome family life. It is known that these standards are not met in the houses now occupied by the people whom it is proposed to reach, otherwise the question would never have been raised. The government's advantage is that it can get money at one or two per cent cheaper than competing builders. This is a small margin and so far as experience shows is not enough to enable it to rehouse, with a five per cent or six per cent net profit, the family of small income at the same rent that family had paid before. Moreover there are some compensating disadvantages. The government, or its subsidiary company, must set aside a sinking fund to pay for the houses when they have outlived their usefulness. Its private competitors often carry no such charge, though perhaps they should, but hope for a rise in land values to recoup them when the building must be demolished. The government then is likely to find itself sooner or later asked; first, to lower its standards--the United States government and the city of Boston have recently agreed to break, or at least bend the law limiting the heights of buildings in Boston so that a federal skyscraper may be erected; second, to forego part or all of the interest due on the investment-that is, make a grant in aid of wages to its tenants; or third, to raise the rents to such an extent that a considerable proportion of the population, and the part that needs it most, cannot afford to live in the municipal dwellings.

Of course there are other things that the government could do. It could exempt wage-earners' dwellings from taxation, which means a grant in aid of wages in somewhat different form. This is proposed in Massachusetts. It could enact minimum wage legislation that will enable the worker to pay an economic rent. But if it does that, what is the use of its facing the dilemma at all? And is its position not weakened if it says to the employer, in effect, you must pay higher wages so my tenants can pay me a profit on my investment?

Then came another argument. The whole scheme is based upon the theory that the government is going to aid a certain class in the community. In the United States, at least, it is unconstitutional to spend public money for the benefit of a class in the community. There are numerous court decisions based upon the giving of bonuses to manufacturers and there is the opinion of the Massachusetts supreme court upon the proposal of the homestead commission to use state money in building homes. ${ }^{4}$

Even if it were constitutional, is it good public policy? There are other classes in the community which find the struggle to maintain a good roof over their heads almost or quite as difficult as that of the skilled wage-

4 See The Commonwealth of Massachusetts House No. 2399 of 1912. Since this opinion was given an amendment to the constitution has been drafted which has passed the iegislature and will probably be submitted to the people next year. 
earner who is being provided for in Toronto. And, in strict justice, if they are to be given government grants of money or credit, why should not all? We are assuming that the discussion deals only with those who are considered self-supporting, not with dependents, defectives or delinquents. who are generally acknowledged to be proper subjects for government. aid or support. Is it not well to maintain this classification? Then, if need be, we can move the line up, classing as dependents those who are not able to earn enough to support themselves decently. Perhaps this raising of the line would take it above the heads of many industrious workers who are sound physically, mentally and morally. If it did we would have to answer some questions that we now incline to shirk, and that government grants in aid of wages ${ }^{5}$ may enable us to continue shirking. Why should not a sound, industrious man be able to house his family decently on his earnings? Is it because he himself lacks training or opportunity? Is it because someone else is profiting unduly at his. expense? Is it because of other reasons that we should know and can change? Answering these questions probably would involve more work than granting government aid, but is it not work that we shall have to do sometime?

Mr. Beer said that "housing is a communal responsibility." Later, at the National Housing Conference in Cincinnati, W. S. B. Armstrong, secretary of his company, compared the provision of houses in a community to the provision of sewers, which is usually undertaken at public expense. Sewers are provided, theoretically at least, and we hope that some day they will be actually, for the entire population. There is no. definite proposal yet that houses be so provided. There then arises the question, for the benefit of what section of the community are they to be provided? Mr. Beer said, "In making provision for that class of labor which industry so much requires, it will give a tremendous impetus to. manufacturing in Ontario." And again, "Large employers of labor may work with the municipality in supplying houses for all their employees. This is a better way of advancing municipal development than by bonusing. ${ }^{6}$ Let the cities and towns of Ontario offer as an inducement for new industries a municipal guarantee of housing bonds, care being taken to provide a sinking fund ample to retire the bonds well within the usable life of the buildings. So the housing conditions of the municipality would be benefited, the workers provided with suitable dwellings, often under present conditions a matter of gravest difficulty, and the well-being of the whole community would be secured rather than the advantage of any one class." Again, "We do not claim that this is a solution of the slum problem. So far the Toronto housing company has engaged itself

${ }^{5}$ It was claimed that the Ontario plan is not a government grant in aid of wages.. See discussion later.

'The italics are Mr. Beer's. 
only to provide housing for the working men upon whom so large a share of our progress depends. Later on we may dó something for other classes of labor. The act provides for the whole principle of housing."

Immediately the question was raised, "Is not this simply another form of bonusing?" Admitting that the act provides 'for the whole principle of housing,' is there any serious proposal to extend the operation of that principle both up and down so as to include the whole community? Admitting that to provide factory employees with good homes partly at public expense will, indirectly, benefit the whole community, how does the argument differ from that advanced in support of straight bonuses which brought new industries and new wealth into the town?

The answer to this was that it is not done at public expense. The government does not advance any money, but simply loans the use of its credit. Without government guarantee, however, it was claimed, the bonds could not have been sold on a five per cent basis, as the Toronto bonds were. Evidently the money was available if the security was ample. The inference was that investors were doubtful as to the ability of the company to meet its obligations, but were confident that the city of Toronto could make good any loss. There probably was no justification for such doubt on the part of the investors; the well-managed Washington sanitary improvement company for instance has persuaded its community that there are few safer investments than that afforded by its five per cent stock. But this doubt apparently was the cause of reluctance to invest without government guarantee. Now admitting, for the sake of the argument, that the fear is justified; if the company extends its operations to such an extent as to meet fairly adequately the needs of the artisan population-taking no account of the pressure that is sure to be brought to bear upon it to provide for those of smaller earning capacity and thereby assume greater risks-is there not danger that it will begin to impair the city's credit? Is there not a chance that interest on city money, borrowed not alone for housing, but for the ordinary purposes of city government, will rise until city money is no longer cheap money? And in that case is not the city paying for the housing of a part of its population?

The answer is that this is far fetched. Perhaps; but the whole question is so big, a little beginning may lead to such great consequences, that far fetching may not be entirely unprofitable.

The above account adds to the discussion at Toronto parts of discussions at other places. For Mr. Beer later presented the Ontario plan of financing at the housing conference in Cincinnati, where it aroused great interest, though two other methods shared the attention of the delegates. One of these was the purely private company plan, so successfully carried out by the Washington sanitary improvement company whose $\$ 500,000$ of five per cent capital stock has a waiting list of would-be purchasers. 
The methods of this company were described in detail at the housing conference the year before. Prudent and careful management hias, during the sixteen years of the company's existence, so increased its assets that it now has a surplus of $\$ 190,000$, and its dwellings are said to be in practically as good condition as when they were erected. It has paid without interruption five per cent on its stock since the first year of its existence.

This company was taken as a model by the Cincinnati sanitary housing company, which was in process of organization at the time of the housing conference in December. It proposed to raise through subscriptions a paid-up capital of $\$ 500,000$ with dividends limited to five per cent. It has not found this an easy task, but the outlook is promising.

The other plan presented at Cincinnati was that of the Massachusetts homestead commission. Strictly speaking, the Massachusetts homestead commission presented three plans, though the greater part of the discussion dealt with the third. First was the limited dividend company, such as the Washington and Cincinnati companies above described. Second was what it calls homestead aid, which applies the principle of the building and loan association to collective developments with participation by the resident. Third was the copartnership plan, distinguished by collective ownership of the property, each resident renting from the company, of which he is a member.

"The advantages of this plan are far reaching," said Arthur C. Comey, the member of the commission who presented it. "Capital may be secured at a very low rate; economies will be effected through wholesale operation and responsibility by the tenant in the property, and he is secured from loss if he has to leave."

The plan is as follows:

A prospective resident must be approved and must take up two shares of common stock. He will pay a reasonable rental and share all surplus profits. Dividends on rent and common stock will be credited in common stock until the value of twenty shares is reached, outside capital being gradually retired. The cost of repairs will be deducted from the twelfth month's rent and the remainder remitted, thus further encouraging care in the use of property. The resident can invest his savings in the company at five per cent. Ownership being common, not individual, he is secured from loss if he has to move away.

The directors will ultimately be elected by common stockholders, but preferred stock will be represented until common stock is about one half paid up. Shares shall be 500 common and 1,500 preferred, of $\$ 100$ each. Common stock shall be paid not less than ten per cent upon allotment and installments of one dollar per month per share. Dividends shall not exceed five per cent. Preferred stock shall be paid in full, dividends not to exceed five per cent cumulative. It may be retired at par on a year's notice. First mortgages at five per cent will be placed -on completed houses up to sixty per cent of their value. A reserve fund 
shall be established after Preferred dividends are paid, at the rate of one per cent per annum until it equals the value of the stock.

With 2,000 shares subscribed 250 houses can be built. The committee will secure options and call a meeting when about one fifth is subscribed.

Mr. Comey in the course of his statement also argued for government aid in financing housing developments, saying that nowhere in the world has private initiative solved the housing problem, consequently it is necessary to seek government aid.

Issue was at once taken on this point. Mr. Armstrong of the Toronto. housing company declared that government aid is not wanted; that the only assistance or aid that constructive housing wants from the government is some form of legislation that will enable us to get large amounts. of capital at a low rate of interest. The improvement of housing must be a business proposition. Another delegate asked if, in view of $\mathrm{Mr}$. Comey's statement that private initiative has everywhere failed, he could' point to an instance where government aid has succeeded in solving the problem. In reply he referred to a report for which the commission. was gathering data that would probably contain the information.

Mr. Armstrong further contended that copartnership housing is not, necessarily, a government aid proposition, that the fundamental idea. in it is community or company control. To the uninformed workingman this means restraint to which he objects, but this restraint is far outweighed by the advantages the plan provides. Other delegates differ from this view, maintaining that there is a moral advantage in free ownership of one's home that the copartnership plan loses. The reply was that it substitutes something of even greater value, a sense of community responsibility. Then came a counter attack on individual ownership; the burden of taxes makes the small house owner oppose public improvements; the burden of paying for the house makes him stint his family on food and clothes; and in the end he has a property whose value may be depreciated at any moment by the action of neighboring owners over whom he has no control.

The financial phase of the plan was sharply attacked. Andrew Wright. Crawford of Philadelphia ${ }^{7}$ declared that coöperation has always been a failure in America and that one of the points claimed in favor of copartnership shows it will ultimately prove a failure in England. Under copartnership labor is assured of mobility because the working man may quickly move from place to place as the copartnership company will, on demand, take his house off his hands. But some day the company will fail and so be unable to pay for the property.

The possibility of financial failure was admitted by advocates of the plan, but one of them, George E. Hooker of Chicago, instanced the great coöperative organizations of Great Britain which, after successive

'See National Municipal Review, Vol. III, page 474. 
failures, have finally struck life and are now among the great business organizations of the country. He was not sure, however, that housing need be considered on a business or profit-making basis, any more than a school or college education, which is not paid for according to value received. But on this point there is apparently difference of opinion in the land from which he drew his illustrations as to what is sound principle for a recent report of the unofficial land inquiry committee (Great Britain) states that the housing problem will be solved only by ensuring the laborer such a rise in wages as will enable him (a) to live in a state of physical efficiency, and (b) to pay a commercial rent for his cottage.

In this discussion Augustus Thorndike, bank commissioner of Massachusetts, told of the opportunities a would-be home owner has in his commonwealth. There are in the state 450 savings banks and coöperative banks with deposits of nearly $\$ 950,000,000$. The savings banks, which are mutual banks, have $\$ 450,000,000$ invested in 140,000 mortgages on real estate; the coöperative banks have 150,000 share-holders and they have 47,000 mortgages on real estate. These coöperative banks are owned by their share-holders and will advance eighty per cent of the cost of a home to any one who has accumulated savings equal to twenty per cent of its value, the security committee, selected from the shareholders of the banks, certifying that the value of the property will be twenty per cent more than the amount of the loan.

One other method of financing small houses was described by Dr. Lee K. Frankel of the Metropolitan life insurance company, at the Massachusetts city and town planning conference held in Boston last fall. Dr. Frankel had, at the National housing conference a year before, described the method by which the Metropolitan advanced approximately $\$ 650,000$ to a building company for the erection of small houses in Brooklyn. The price of a house was $\$ 5,500$. The life insurance company took a first mortgage of $\$ 3,250$ payable in semi-annual installments during a period of twenty years. The building company took a second mortgage of $\$ 1,500$ payable in quarterly installments during a period of twelve years. The purchaser made an initial payment of $\$ 750$. This figured out, with taxes, water rates and fire insurance, a total annual payment of $\$ 522.98$ during the first twelve years, or an average of $\$ 43.58$ per month, and a total annual payment during the last eight years of $\$ 346.70$, or an average of $\$ 29$ per month.

At the Boston conference Dr. Frankel described a more recent experiment by the Metropolitan in assisting in the erection of small houses, which indicates that the funds of these great corporations can be used to improve housing conditions for people of smaller means and, by so doing, improve the health of communities of which their policy holders form so large a part. This second experiment was made in coöperation with Frank A. Seiberling, president of the Goodyear tire and rubber company 
of Akron, Ohio. The insurance company loaned $\$ 86,000$ for the construction of houses on the outskirts of Akron. This loan was made to Mr. Seiberling and is doubly protected by a mortgage on the individual houses and a bond by the Goodyear Heights realty company, a subsidiary of the Goodyear tire and rubber company. These houses form part of a garden suburb development which is convenient of access to the factory and to the center of the city.

The land was purchased as acreage at $\$ 300$ per acre, making the purchase cost of the 100-acre tract $\$ 30,000$. Improvements, excavating, road and sidewalk building, sewers, grading, planting, etc., brought the total cost to $\$ 210,675$ which was distributed among the 430 lots into which the tract was divided. Some of these lots sell as low as $\$ 240$, others as high as $\$ 760$. The Goodyear company disclaims any intention of making a profit on the development, its purpose, apparently, being similar to that of some of the subsidiaries of the United States Steel corporation and other manufacturing concerns which build dwellings for their employees and rent them at low rates on the theory that, while they do not bring in a direct return on the investment, they do increase the efficiency of the business, and thus pay for themselves.

The selling price of house and lot is then figured on an actual cost basis, to which twenty-five per cent is added in order to prevent speculation on the part of purchasers. On this amount two mortgages are placed, both at six per cent. The first mortgage is taken by the Metropolitan life insurance company for about one half the value of the property; the second by the Goodyear company, covering the balance of the purchase price. No initial cash payment is demanded. The purchaser pays the Goodyear company in semi-monthly installments, the first mortgage being paid off in fifteen years, the second in twelve. Opportunities are given the purchaser to make additional payments at any time within these periods. At the end of five years the company credits the purchaser with twenty-five per cent of the purchase price, plus interest.

Dr. Frankel presented a series of tables showing just how this plan works out and how it can be combined with a life insurance policy which will clear the property of all encumbrance in case the bread-winner dies before the completion of the fifteen-year period. The payments on the property, exclusive of life insurance, would, for a property costing $\$ 2,288$ -real estate value $\$ 2,860$ or twenty-five per cent additional-be $\$ 6.03$ semi-monthly during the first five years and $\$ 4.44$ semi-monthly during the remaining ten years, for the first mortgage, and $\$ 6.98$ semi-monthly during the first five years and $\$ 4.01$ semi-monthly for the remaining seven years for the second mortgage.

The plans outlined above, the use of government credit or money, the simple limited dividend method, the coöperative bank loans, the copartnership scheme, the use of funds supplied by a life insurance company, 
do not cover all the proposals now being made for the financing of small houses. Nor have the discussions of these plans been thorough enough to warrant us in either accepting unreservedly or discarding any one of them. The question is still open and further light may cause us to change present opinions. These plans do, however, embody the principles along which the builders of wage-earners' dwellings are working and they have behind them most of the experience now available as a basis for discussion. It may be that the Ontario method and the use of government money will not lead Toronto and Massachusetts into the dangers prophesied, or into others not now foreseen. It may be that limited dividend companies can secure ample capital. It may be that copartnership will prove a financial and social success. It may be that the great funds of the insurance companies may be made more and more readily available and at lower rates. We are still very near the beginning of our attempt to find a better method than the traditional ones of financing small houses. The important point is that many men in many places are working on the problem by different methods. In time the pragmatic test will enable us to decide which is the best. 